\title{
NAJTRUDNIEJSZE LATA WIELKIEGO WODZA? JAN III A WYSIŁEK WOJENNY RZECZYPOSPOLITEJ W LATACH 1690-16961
}

\author{
Jan Jerzy Sowa \\ http://orcid.org/0000-0002-9507-7574 \\ Uniwersytet Warszawski
}

\section{ABSTRACT \\ THE HARDEST YEARS OF THE GREAT COMMANDER? JOHN III AND THE MILITARY EFFORT OF THE POLISH-LITHUANIAN COMMONWEALTH IN 1690-1696}

The paper presents actions of John III as related to waging war against the Ottoman Empire in 1690-1696. It was arguably the most difficult period of his reign because of the constitutional and fiscal crisis of the Polish-Lithuanian Commonwealth. One of the main military duties of the king was the overall coordination of the military effort. The ruler mediated between military commanders and informed the public opinion about the course of warfare. He also vigorously acted within the Council of Senate for better garrisoning and provisioning of the frontier fortresses. Even though the result of the final years of John Sobieski's reign cannot be regarded as positive (also because of the king's political mistakes), his military activity in 1690-1696 probably exhausted all his possibilities within the frames of the constitution of the Commonwealth and he could do nothing more to support the Polish-Lithuanian military effort.

Keywords: Council of Senate, garrisons, hetmans, John III Sobieski, military command, military officers, Polish-Lithuanian Commonwealth, Stanisław Jabłonowski, Zaporozhian Cossack Army.

Słowa kluczowe: dowodzenie, garnizony, hetmani, Jan III Sobieski, polsko-litewska Rzeczpospolita, oficerowie, rady senatu, Stanisław Jabłonowski, wojsko zaporoskie.

1 Artykuł powstał w ramach projektu „Sądownictwo i dyscyplina wojskowa w Rzeczypospolitej końca XVII w.” Narodowego Centrum Nauki (nr : 2014/13/N/HS3/04407) i jest zmodyfikowaną wersją tekstu już opublikowanego: https://sobieski1683.p1/2017/07/04/jan-jerzy-sowa-dzialalnosc-wojskowa-jana-iii-w-latach-1690-1696/ [dostęp: 3.05.2018]. Autor jest stypendystą Fundacji Augusta hr. Cieszkowskiego (edycja 2018). 
Głównym napędem błyskotliwej kariery Jana Sobieskiego, zwieńczonej wyniesieniem na tron w 1674 roku, były jego zdolności militarne, czy też szerzej - cała jego działalność wojskowa. Nie powinno zatem dziwić, że również po uzyskaniu korony sprawy wojskowe pozostały centralnym przedmiotem jego zainteresowania. Monarcha w dalszym ciągu starał się prezentować opinii publicznej przede wszystkim jako zwycięski wódz ${ }^{2}$. Należy jednak zwrócić uwagę, że jego aktywność militarna, zarówno jako hetmana, jak i króla, nie ograniczała się wyłącznie do przewodzenia żołnierzom na polu walki. Co więcej: w czasie wojny Ligi Świętej (1684-1699) było to rzadkością - już w trakcie kampanii 1685 roku Jan III zrezygnował z bezpośredniego dowodzenia armią, a w ostatniej dekadzie swoich rządów stanął na czele wojska tylko raz - w 1691 roku. Mimo to nadal przeważająca część działalności publicznej monarchy była związana z prowadzeniem wojny z imperium osmańskim. Wysiłkom tym (z wyłączeniem wojskowej polityki personalnej Sobieskiego, która jest przedmiotem osobnego opracowania $w$ niniejszym tomie ${ }^{3}$ ) w ostatnich sześciu latach panowania króla poświęcono niniejszy szkic. Datę początkową wybrano z uwagi na ostatni za życia Jana III sejm zakończony uchwaleniem konstytucji i nałożeniem podatków. Następne lata miał cechować bardzo głęboki kryzys polityczny, uniemożliwiający skuteczne sejmowanie, jak również powiązany z nim poważny kryzys finansów państwa ${ }^{4}$. Wprost wyrażał to w grudniu 1695 roku hetman wielki koronny Stanisław Jabłonowski na wieść o braku porozumienia pomiędzy hetmanem wielkim litewskim, wojewodą wileńskim Kazimierzem Janem Sapiehą a biskupem wileńskim Konstantym Brzostowskim: „żałosna rzecz, że ad aerumnas temporum, tej zgody Wielkiego Księstwa Litewskiego niedojście, wielki czyni przydatek, bo się pomyślnego sejmu skutku (w którym securitas periclitantis Rei Publicae zawisła) ledwie się spodziewać godzi”' B. Był to zatem, jeśli chodzi o samą organizację wysiłku wojennego, najtrudniejszy okres rządów Sobieskiego, zwłaszcza że króla coraz częściej trapiły wówczas problemy zdrowotne, w dużym stopniu utrudniające sprawowanie funkcji publicznych. Należy jednak wyraźnie podkreślić, wbrew stanowisku prezentowanemu w części starszej literatury przedmiotu, że do końca życia Sobieski

2 Najnowsze opracowanie na temat powiedeńskiej propagandy wojennej Jana III: A. Czarniecka, Ojczyzna czy Liga Święta? Koalicja antyturecka w propagandzie za czasów Jana III Sobieskiego (1684-1696) [w:] Jarzmo Ligi Świętej? Jan III Sobieski i Rzeczpospolita w latach 1684-1696, red. D. Milewski, Warszawa 2017, s. 81-108.

3 Z. Hundert, Patronat wojskowy $w$ dobie Sobieskiego 1667-1696. Rola, znaczenie, postulaty badawcze.

4 Ostatnio ukazała się na ten temat m.in. praca: R. Kołodziej, Funkcjonowanie systemu podatkowego Rzeczypospolitej i jego wplyw na wojnę z Turcja w czasach Jana III Sobieskiego [w:] Pecunia nervus belli. Z dziejów dyplomacji i stosunków międzynarodowych w XV-XVII wieku, red. M. Markiewicz, R. Skowron, F. Wolański, Prace Naukowe Uniwersytetu Śląskiego w Katowicach, nr 3448, Katowice 2016, zwłaszcza s. 240-241.

S. Jabłonowski do Jana III, Lwów, 21 XII 1695, Archiwum Główne Akt Dawnych w Warszawie [dalej: AGAD], Zbiór dokumentów papierowych [dalej: ZDPap.], rkps 2600, [brak paginacji]. 
interesował się kwestiami wojskowymi i zachował wpływ na podstawowe kierunki polityki Rzeczypospolitej w tym zakresie ${ }^{6}$.

Do podstawowych zadań króla w ramach prowadzenia wojny należały między innymi ogólna koordynacja wysiłku wojennego, mediowanie pomiędzy poszczególnymi dowódcami, a także informowanie opinii publicznej o przebiegu działań wojennych, zawsze połączone z zachętami do większej ofiarności społeczeństwa na rzecz wojska - w tym aspekcie militarne kompetencje panującego ściśle łączyły się z jego prerogatywami w systemie parlamentarnym Rzeczypospolitej. Władca był odpowiedzialny również za działania o charakterze dyplomatycznym, związane bezpośrednio z prowadzeniem wojny. Wreszcie - Jan III podejmował najważniejsze decyzje dotyczące organizacji i działań wojska zaporoskiego, aczkolwiek zazwyczaj w kwestiach kozackich ściśle współpracował $\mathrm{z}$ hetmanem wielkim koronnym ${ }^{7}$.

Do sprawnej realizacji tych funkcji konieczny był szybki przepływ informacji pomiędzy monarchą a dowództwem armii koronnej i litewskiej. Zachowane zbiory korespondencji, zarówno trafiającej do króla ${ }^{8}$, jak i wychodzącej od dworu', wskazują na bardzo ożywioną wymianę listów z hetmanami koronnymi i litewskimi oraz niektórymi oficerami niższego szczebla - przede wszystkim z generałem artylerii koronnej, wojewodą kijowskim Marcinem Kątskim i komisarzem wojska zaporoskiego, kasztelanem chełmskim Stanisławem Zygmuntem Druszkiewiczem. Główną rolę w kontaktach wojskowych z Janem III odgrywał hetman wielki koronny, wojewoda ruski, a następnie kasztelan krakowski Stanisław Jabłonowski. Listy pozostałych hetmanów pisane $\mathrm{z}$ obozu do króla nierzadko miały charakter w sporej mierze kurtuazyjny, a ich nadawcom zdarzało się otwarcie pisać, że w przedmiocie informowania o przebiegu działań wojennych zdają się na hetmana wielkiego koronnego ${ }^{10}$. Jabłonowski przekazywał też Sobieskiemu listy innych oficerów adresowane do króla albo

${ }_{6}$ Zwracał na to uwage już Z. Wójcik, Jan Sobieski 1629-1696, wyd. 2, Warszawa 1994, s. 471472 (pierwsze wydanie 1983).

7 Dlatego też komputy wojska zaporoskiego można znaleźć zarówno w archiwum wojskowym hetmana wielkiego koronnego Stanisława Jabłonowskiego, np. Komput wojska JKM i Rzeczypospolitej zaporoskiego [...] in anno 1694, Biblioteka XX. Czartoryskich w Krakowie [dalej: B. Czart.], rkps 2699, k. 207v, jak i w materiałach archiwalnych pochodzących z bezpośredniego otoczenia Jana III, np. Płaca i barwa wojsku kozackiemu schodzącemu z pola, AGAD, Archiwum Publiczne Potockich [dalej: APP], rkps 47, t. 2, XII 1695, s. 601-607.

8 Нацыянальны гістарычны архіў Беларусі, Мінск [dalej: НГАБ], f. 695, vop. 1, zwłaszcza rkps $48,55,60,99-100,142$.

9 Dla interesującego nas okresu będzie to przede wszystkim Российский государственный архив древних актов, Москва [dalej: РГАДА], f. 12, op. 1, ks. 22 (za wskazanie tego rękopisu pragnę serdecznie podziękować p. drowi Przemysławowi Gawronowi i p. drowi Krzysztofowi Kossarzeckiemu). Ponadto liczne pisma Jana III z lat 1694-1695 pochodzące z rękopisu Biblioteki Załuskich nr 439 znajdują się w B. Czart., Teka Naruszewicza [dalej: TN], rkps 184.

10 K.J. Sapieha do Jana III, obóz pod Okopami Świętej Trójcy, 9 X 1692, НГАБ, f. 695, vop. 1, rkps 142, k. 34-35; K.J. Sapieha do Jana III, Wysokie Litewskie, 10 VII 1693, AGAD, ZDPap., rkps 2595, [brak paginacji]; S. Potocki do Jana III, Sokal, 13 VII 1693, AGAD, ZDPap., rkps 2597, [brak paginacji]; S. Potocki do Jana III, obóz pod Seńkowcami, 9 X 1695, НГАБ, f. 695, vop. 1, rkps 55, k. 196. 
do siebie - jako załączniki do własnej korespondencji ${ }^{11}$. Wreszcie liczni przedstawiciele elit wojskowych - znowu na czele z Jabłonowskim i Kątskim - utrzymywali stałą korespondencję z „prawą ręką” Jana III - referendarzem koronnym Stanisławem Antonim Szczuką ${ }^{12}$. Warto także zauważyć, że wojskowi bardzo często osobiście gościli na dworze królewskim w Żółkwi i w Wilanowie ${ }^{13}$. Do Żółkwi trafiała również część wziętych do niewoli nieprzyjació $1^{14}$. Trudno ocenić, w jakim stopniu stała za tym rzeczywista chęć króla (znającego przecież przynajmniej podstawy języka tureckiego i tatarskiego), by osobiście przesłuchać jeńców, a w jakim - był to zabieg propagandowy - element spektaklu mający utwierdzić goszczących na dworze w przekonaniu o pomyślnym przebiegu wojny.

Instrumentem, za którego pośrednictwem monarcha sprawował ogólne kierownictwo nad wysiłkiem wojennym Korony i Litwy, były rady senatu, nazywane niekiedy wprost radami wojennymi (consilium bellicum), zwłaszcza gdy uczestniczyli w nich hetmani ${ }^{15}$. Warto zwrócić uwagę, że w interesującym nas okresie wiadomo o co najmniej osiemnastu posiedzeniach rady senatu (odbywających się z bardzo różną częstotliwością), a ostatnie z nich odbyło się w Wilanowie 2 czerwca 1696 roku, a zatem dwa tygodnie przed śmiercią monarchy. Gros punktów poruszanych na radach senatu było siłą rzeczy związanych z toczącą się wojną ${ }^{16}$. Do dużego znaczenia tego gremium niewątpliwie przyczyniał się fakt, że mogło ono, obok sejmu, autoryzować wypłatę pieniędzy ze skarbu koronnego. Dlatego też hetmani, potrzebując dodatkowych środków, przedstawiali te prośby najczęściej na senatus consilium.

Jedną z najważniejszych kwestii poruszanych na radach senatu pod koniec panowania Jana III była sprawa zaopatrzenia fortec na Podolu, Ukrainie i w Mołdawii (najważniejszymi z nich były: Biała Cerkiew, Kimpulung, Niemirów, Okopy Świętej Trójcy, Niemiec, Soroka, Suczawa i Szaniec Panny Marii ${ }^{17}$. Doskonale zdawano sobie sprawę, że wobec niezdobycia Kamieńca Podolskiego są one najważniejszym atutem przetargowym Rzeczypospolitej podczas ewentualnych rokowań pokojowych (co w pełni potwierdziło się na kongresie karłowickim). Liczono, że zaopatrzenie zostanie sfinansowane z subsydiów papieskich, jednakże współpraca z kolejnymi papieskimi komisarzami do wypłaty subsydiów, o. Franceskiem Bonesaną CRT i o. Sebastianem Accorsim CRT, przy zakupie, magazynowaniu i transporcie prowiantu nie układała się najlepiej - w związku z tym hetman Jabłonowski nierzadko

11 Np.: M. Złotnicki do S. Jabłonowskiego, obóz pod Wiśniowczykiem, 9 VIII 1693, НГАБ, f. 695, vop. 1, rkps 48, k. 86v-87v; M. Brandt do S. Jabłonowskiego, Okopy Świętej Trójcy, 23 VI 1695, НГАБ, f. 695 , vop. 1, rkps 142, k. 122-122v; K. Zahorowski do Jana III, [b.m.d.], НГАБ, f. 695, vop. 1, rkps 55, k. 308.

12 Zob. odnośne tomy tzw. Tek Szczuki: AGAD, APP, rkps 163-163a, passim.

13 K. Sarnecki, Pamiętniki z czasów Jana Sobieskiego. Diariusz i relacje z lat 1691-1696, oprac.

J. Woliński, Wrocław 1958, passim.

14 Np. ibidem, s. 58; K.J. Sapieha do Jana III, Hrubieszów, 7 VIII 1693, AGAD, ZDPap., rkps 2596, [brak paginacji]; S. Jabłonowski do Jana III, Lwów, 2 ХІ 1695, НГАБ, f. 695, vop. 1, rkps 99, k. 81.

15 K. Sarnecki, op. cit., s. 186-187.

16 J. Krupa, Rady senatu za Jana III Sobieskiego, „Studia Historyczne” 1992, R. XXXV/3, s. 316317, 327-328.

17 Zob. protokoły rad senatu z lat 1693-1695: AGAD, APP, rkps 48, s. 30-31. 
interweniował w tej kwestii u monarchy ${ }^{18}$. Kiedy po 1692 roku Stolica Apostolska przestała subsydiować Rzeczpospolitą, w miarę skromnych możliwości skarbu koronnego starano się asygnować środki finansowe na zakup żywności, prochu i amunicji dla polskich garnizonów na terytorium nieprzyjacielskim ${ }^{19}$.

Dużo uwagi na radach senatu poświęcano także kondycji wojsk autoramentu cudzoziemskiego. Teoretycznie na pokrycie tytularnym oberszterom kosztów zaopatrzenia, umundurowania i dodatkowych zaciągów sejm uchwalił w 1677 roku znaczącą podwyżkę żołdu dla piechoty i dragoniii ${ }^{20}$. W rzeczywistości, jak wielokrotnie skarżył się hetman Jabłonowski: „Panowie pułkownicy cale nie dbali na swoje regimenty”21. W związku z tym, że piechota znajdowała się w dużo trudniejszej sytuacji zaopatrzeniowej niż jazda, dragonia praktycznie podczas każdej kampanii „odpadała” od koni $^{22}$, a ponadto jednostki zaciągu cudzoziemskiego trapiła dezercja ${ }^{23}$, konieczne było częste uzupełnianie składu tych jednostek. Wymagało to z jednej strony wypłaty środków ze skarbu koronnego, a z drugiej - zgody na przeprowadzenie werbunku w położonych wewnątrz kraju królewszczyznach, co z kolei spotykało się z nieprzychylnymi opiniami społeczeństwa szlacheckiego, starającego się trzymać wojsko jak najdalej od centralnych obszarów Korony. Choć asygnacje dla oficerów z pozwoleniem na werbunek rekrutów w poszczególnych miastach i starostwach wydawał hetman ${ }^{24}$, zazwyczaj starał się uzyskać dla swoich działań poparcie ze strony rady senatu ${ }^{25}$.

Przedmiotem zainteresowania rad senatu była również sytuacja artylerii koronnej i litewskiej ${ }^{26}$. Formacja ta powinna być utrzymywana $z$ dochodów z nowej kwarty, ale także w tym przypadku teoria rozmijała się z praktyką i konieczne było wyasygnowanie dodatkowych środków na wyprowadzenie armat w pole. Powodowa-

18 S. Jabłonowski do Jana III, Lwów, 12 II 1691, НГАБ, f. 695, vop. 1, rkps 99, k. 14-15; S. Jabłonowski do Jana III, Lwów, 26 IV 1691, НГАБ, f. 695, vop. 1, k. 16-16v.

19 Rachunki generalne sejmowe Najjaśniejszemu Królowi Janowi III i wszytkim stanom Rzeczypospolitej na sejm walny grodzieński pro die 31 XII w roku 1692 złożony zgromadzonym od Skarbu Rzeczypospolitej Koronnego podane, AGAD, Archiwum Skarbu Koronnego, dz. II, rkps 73, k. 26-26v; Rachunki generalne sejmowe Najjaśniejszemu Królowi JeM Augustowi II i wszytkim stanom Rzeczypospolitej na sejm walny warszawski pro die 16 VI w roku 1699 złożony zgromadzonym od Skarbu Rzeczypospolitej Koronnego podane, Archiwum Skarbu Koronnego, dz. II, rkps 74, k. 38-38v.

20 Uzasadnienie tej podwyżki: Konotacja wiele wychodzi na regiment verbi gratia ludzi numero 300 mający pożytek oficyjerski i żołd i co się na pułkownika zostaje rachując po zł 36 na ćwierć, jako niektórzy IchM po nas potrzebują, B. Czart., rkps 426, s. 172.

21 Np. S. Jabłonowski do Jana III, Lwów, 15 IV 1693, AGAD, APP, rkps 47, t. 2, s. 550-553; S. Jabłonowski do Jana III, Busk, 1 VI 1693 [w:] Starożytności historyczne polskie, wyd. A. Grabow ski, t. 2, Kraków 1840, s. 512-514.

22 S. Jabłonowski do M. Złotnickiego, Lwów, 18 VII 1692, B. Czart., rkps 2699, k. 57-58; S. Jabłonowski do Jana III, obóz pod Wierzbowem, 18 X 1692, НГАБ, f. 695, vop. 1, rkps 99, k. 29.

23 S. Jabłonowski do Jana III, Lwów, 15 IV 1693, AGAD, APP, rkps 47, t. 2, s. 550-553.

24 Przykład takiej asygnacji: asygnacja Stanisława Jabłonowskiego dla regimentu arkabuzerskiego JKM, Lwów, 30 XI 1693, B. Czart., rkps 2699, k. 183v.

25 Np. Punkta do rady na dzień 16 miesiąca kwietnia naznaczonej z Kancelaryi Koronnej od JKrMci, Warszawa, 16 IV 1695, Biblioteka Uniwersytecka w Warszawie, rkps 357, s. 38-41.

26 Ibidem, s. 38-41; J. Krupa, op. cit., s. 328. 
ne to było między innymi znacznym wzrostem kosztów wynajmu zaprzęgów, jak również amunicji w trakcie trwania wojny ${ }^{27}$. Duże znaczenie dla artylerii koronnej miało to, że na jej czele stał długoletni towarzysz broni Jana Sobieskiego - Kątski. Dzięki bezpośredniemu dostępowi do króla mógł on w pełni przedstawiać potrzeby artylerzystów i uzyskać dodatkowe pieniądze na ten cel. Było tak na przykład pod koniec 1695 roku. W listopadzie tego roku generał artylerii koronnej prosił o wyasygnowanie ze skarbu koronnego 60 tysięcy złotych w dwóch ratach na utrzymanie artylerii koronnej - przede wszystkim na pokrycie kosztów wynagrodzeń personelu artyleryjskiego:

najbardzi idzie o oficierów i ludzi in genere wszystkich w tej służbie zostających, którech niepodobna by bez zapłaty utrzymać, a practicos i doświadczonech utraciwszy, nie wiem, jako i skąd inszech zaciągnąć. Podawszy to tedy miłościwej konsyderacyjej WKM PmM i Jego dobrotliwej prowidencyjej, pokornie suplikuję, abym pożądaną w tem mógł otrzymać deklaracją ${ }^{28}$.

Dokładnie miesiąc później rada senatu w całej rozciągłości przychyliła się do przedstawionej przez króla prośby Kątskiego ${ }^{29}$.

$\mathrm{Na}$ radach senatu poruszano także problem wynagrodzenia i lokacji wojska zaporoskiego $^{30}$. Żołd dla Kozaków, inaczej niż w przypadku wojska komputowego, nie był ujęty w konstytucjach sejmowych, stąd też wypłata jakichkolwiek pieniędzy dla Zaporożców wymagała zgody przynajmniej rady senatu. W początkowym okresie wojny liczono, że wojska kozackie będą finansowane przez Stolicę Apostolską w ramach subsydiów dla Rzeczypospolitej. Jednakże narastające trudności z uzyskaniem środków od papiestwa zmuszały skarb koronny do przeznaczenia na ten cel własnych pieniędzy ${ }^{31}$. Było to konieczne, choćby w związku z narastaniem od końca lat 80. buntowniczych nastrojów w wojsku zaporoskim (przede wszystkim na skutek działalności pułkownika Semena Palija). W latach 90. dochodziło nawet do krótkotrwałych konfliktów zbrojnych pomiędzy wojskiem koronnym a sprzyjającymi Palijowi prawobrzeżnymi Kozakami ${ }^{32}$.

27 W 1689 r. generał Marcin Kątski szacował, że wyprowadzenie w pole artylerii koronnej na pół roku będzie kosztowało co najmniej $404700 \mathrm{zł}$ (planowano wynajęcie 1575 koni), zob. Memoriał dział, moździeżów i amunicjej różnej, które na teraźniejszą kampanią w pole wyprowadzić potrzeba in anno 1689, B. Czart., rkps 2563, s. 2-3. Na wysokie koszty wynajmu zaprzęgów skarżył się też hetman Stanisław Jabłonowski do Jana III, Lwów, 15 IV 1693, AGAD, APP, rkps 47, t. 2, s. 550-553.

28 M. Kątski do Jana III, Lwów, 16 XI 1695, AGAD, ZDPap., rkps 2598, [brak paginacji].

29 Punkta do rady na dzień 16 miesiąca kwietnia naznaczonej z Kancelaryi Koronnej od JKrMci, Warszawa, 16 IV 1695, Biblioteka Uniwersytecka w Warszawie, rkps 357, s. 38-41.

30 J. Krupa, op. cit., s. 327-328.

31 Т. Чухліб, Документи про фінансування козацьких полків Ватиканом та Польщеюо у 8090-х роках XVII cm., „Український археографічний збірник” (Nowy Jork) 2002, Вип. 10, s. 340-356; M. Wagner, Kampania żwaniecka 1684 roku, Warszawa 2013, s. 47, 52.

32 Ostatnio na ten temat pisał: M. Wagner, Baltazar Wilga Godzimirski-ostatni komisarz kozacki Rzeczypospolitej (1692-1699), „Zeszyty Naukowe Uniwersytetu Jagiellońskiego. Prace Historyczne” 2016, nr 2 (143): Ukraina, Ruś w epoce nowożytnej. Instytucje i elity, red. J. Stolicki, W. Michałowski, s. 329-331. O starciach z oddziałami Palija informował Jana III Stanisław Zygmunt Druszkiewicz: S.Z. Druszkiewicz do Jana III, Niemirów, 21 X 1692, НГАБ, f. 695, vop. 1, rkps 55, k. 104-105v. 
Osobnym zagadnieniem była kwestia lokacji wojska zaporoskiego. O ile bardzo drażliwą i konfliktową sprawę lokacji wojska koronnego, przynajmniej teoretycznie, rozwiązywały konstytucje i skrypt ad archivum uchwalone na sejmie 1690 $\mathrm{roku}^{33}$, o tyle nie istniały podobne regulacje dotyczące lokowania Zaporożców. Konflikt nasilał się podczas trwania wojny, w miarę powrotów polskich posesorów i ich zarządców na Bracławszczyznę i Kijowszczyznę ${ }^{34}$. Szczególną wagę miał spór o kwaterowanie Kozaków w ich głównej siedzibie - Niemirowie - należącym oficjalnie najpierw do Jana Kazimierza Zamoyskiego, wojewody bełskiego, a potem do Józefa Potockiego, starosty halickiego. Ostatecznie senatorowie podjęli decyzję o podpisaniu kontraktów z obydwoma posesorami, aby z odpowiednią gratyfikacją pozwolili Kozakom kwaterować w Niemirowie ${ }^{35}$. Porozumienia te nie zakończyły jednak konfliktów i do końca wojny do hetmanów i na dwór docierały doniesienia o waśniach pomiędzy mołojcami a próbującymi ich wyrugować $\mathrm{z}$ dóbr swoich patronów zarządcami majętności magnackich ${ }^{36}$. Jan III musiał wręcz osobiście upominać niechętnych wojsku zaporoskiemu posesjonatów ${ }^{37}$. Mimo to jeszcze pod koniec 1695 roku Jabłonowski gorzko zauważał:

Nigdym takiego kłopotu nie miał, jako teraz z lokacją Kozaków naszych, bo ich nigdzie w Ukrainie i Polesiu puścić nie chcą. Przeszłymi czasy po kilkanaście chorągwi zimowało w Polesiu. Teraz żadnej tam nie puściłem chorągwi, a przecie nie masz kędy lokować Kozaków, którzy jako są potrzebni i co za akcje robią, kożdy widzi a po staremu dyskrecyjej nie mają ichmciowie na nich ${ }^{38}$.

Część magnatów jednak sama (przynajmniej częściowo na własny koszt) zaciągała własne oddziały kozackie, by na ich czele służyć Rzeczypospolitej i tym samym zaprezentować się przed monarchą i szlachtą jako kandydaci do ewentualnych awansów. Tak postąpił na przykład starosta kazimierski Jerzy Dominik Lubomirski, który na czele zwerbowanych przez siebie Kozaków w 1694 roku na rozkaz Jana III przeprowadził łupieżczy rajd przeciw wiernym sułtanowi Kozakom hetmana Stecia

33 Konstytucja Lokacyja wojska i skryptu ad archivum danego aprobacyja [w:] Volumina legum, t. V, wyd. J. Ohryzko, Petersburg 1860, s. 372-373; Skrypt ad archivum dany na sejmie walnym warszawskim, [Warszawa, 6 V 1690], oprac. J.J. Sow a [w:] P. Smolarek, Kampania mołdawska Jana III roku 1691, do druku przygotowali Z. Hundert, M. Wagner, Oświęcim 2015, s. 85-90.

34 Zob. S. Palij do Jana III, Fastów, 29 VIII 1694 [w:] M. Nagielski, Listy z teatru działań przeciwko Turcji i Tatarom do Jana III Sobieskiego w zbiorach Archiwum Historycznego Białorusi w Mińsku [w:] Państwo, demokracja, chtopi. Studia z historii społeczno-politycznej Polski (XVII-XX w.). Tom studiów dedykowany profesorowi Romualdowi Wacławowi Turkowskiemu z okazji 65-lecia urodzin i 40-lecia pracy dydaktyczno-naukowej, red. S.J. Pastuszka, J. Sztejnbi s-Zdyb, Warszawa 2016, s. 516-517.

35 Punkta do rady na dzień 16 miesiąca kwietnia naznaczonej z Kancelaryi Koronnej od JKrMci, Warszawa, 16 IV 1695, Biblioteka Uniwersytecka w Warszawie, rkps 357, s. 38-41.

36 S.Z. Druszkiewicz do Jana III, Niemirów, [przed 19 VIII 1692] [w:] M. Nagie1ski, op. cit., s. $509-510$.

37 Jan III do J.A. Koniecpolskiego i J. Potockiego, [b.m.] 1694, B. Czart., TN, rkps 184, s. 587-588.

38 S. Jabłonowski do Jana III, Lwów, 9 XI 1695, НГАБ, f. 695, vop. 1, rkps 99, k. 83. 
(Stepana Łozińskiego) w okolicach Kiszyniowa i Dubosar ${ }^{39}$. Rok później Lubomirski mógł się cieszyć uzyskaniem urzędu podstolego koronnego ${ }^{40}$.

Rady senatu troszczyły się także o poszczególnych żołnierzy, zwłaszcza tych szczególnie zasłużonych dla Rzeczypospolitej. Dlatego też podejmowały decyzje o specjalnych wynagrodzeniach dla oficerów, którzy popadli w kłopoty finansowe (np. gen. mjr Wacław Wilhelm Dobszyc w 1695 r.), czy też o wykupie żołnierzy, którzy dostali się w trakcie działań wojennych do niewoli tureckiej bądź tatarskiej (np. por. Mikołaj Tyszkowski, pojmany pod Hodowem w 1694 r., czy też por. Stanisław Jastrzębski, wzięty do niewoli w bitwie pod Lwowem w 1695 r.) ${ }^{41}$.

Zasadnicze dla zrozumienia działalności wojskowej Jana III w ostatnim okresie jego rządów są relacje monarchy $z$ hetmanem Stanisławem Jabłonowskim. Kasztelan krakowski niewątpliwie był w tym czasie najważniejszą postacią w wojsku koronnym i wywierał największy wpływ na kierunek jego działann ${ }^{42}$. Niemniej jednak hetman ciągle czuł się w obowiązku konsultować z monarchą wszystkie ważniejsze posunięcia wojska koronnego. Cały czas podkreślał, że przede wszystkim jest wykonawcą poleceń królewskich i niekiedy rzeczywiście organizował pewne przedsięwzięcia na wyraźne polecenia króla (np. podjazd pod Kamieniec Podolski w sierpniu 1692 r. ${ }^{43}$ ). Wzajemna korespondencja Sobieskiego i Jabłonowskiego doskonale ukazuje, że sprawą szczególnie interesującą monarchę była kwestia regularnego wysyłania konwojów z zaopatrzeniem do pogranicznych garnizonów ${ }^{44}$. Zdarzały się sytuacje, że Jabłonowski bardzo dokładnie tłumaczył się Sobieskiemu z podjętych działań. Dobrym przykładem takiego postępowania jest kampania roku 1692. Na wrześniowej radzie wojennej w Brzeżanach ustalono, że wojska polsko-litewskie wybudują i obsadzą fort nad Dniestrem, który będzie blokował dostawy zaopatrzenia (zahary) dla garnizonu osmańskiego w Kamieńcu, a równocześnie podejmą próbę zdobycia twierdzy kamienieckiej5. Po przybyciu na miejsce okazało się, że siły polsko-litewskie są zbyt słabe, aby jednocześnie realizować te dwa przedsięwzięcia, a ponadto zbliżał się koniec pory wojennej. Dlatego też hetman zdecydował wszystkie siły skierować do wsparcia budowy nowych umocnień (nazwanych Okopami Świętej Trójcy), a z prób zdobycia Kamieńca tamtej jesieni zrezygnować. W kilku listach do króla bardzo dokładnie przedstawiał sytuację wojska koronnego i bardzo obszernie wywodził racje,

39 J.D. Lubomirski do Jana III, Połonne, 6 X 1693, AGAD, APP, rkps 47, t. 2, s. 560-562.

40 Urzędnicy centralni i nadworni Polski XIV-XVIII wieku. Spisy, red. A. Gąsiorowski, Kórnik 1992, s. 134.

${ }^{4}$ Punkta do rady na dzień 16 miesiąca kwietnia naznaczonej z Kancelaryi Koronnej od JKrMci, Warszawa, 16 IV 1695, Biblioteka Uniwersytecka w Warszawie, rkps 357, s. 38-41.

42 M. Wagner, Stanisław Jablonowski (1634-1702). Polityk $i$ dowódca, t. II, Siedlce 1997, s. $129-176$.

43 S. Jabłonowski do S.A. Szczuki, Lwów, 16 VII 1692, AGAD, APP, rkps 163a, t. 20, s. 319-320; S. Jabłonowski do M. Złotnickiego, Lwów, 18 VII 1692, B. Czart., rkps 2699, k. 57-58.

44 Np. S. Jabłonowski do Jana III, [b.m.], 11 IX 1692 [w:] Starożytności historyczne polskie..., s. 503; S. Jabłonowski do Jana III, obóz pod Żwańcem, 9 X 1692 [w:] Starożytności historyczne polskie..., s. 506-509; S. Jabłonowski do Jana III, Lwów, 10 XI 1692 [w:] Starożytności historyczne polskie..., s. 509-510.

45 M. Wagner, Stanistaw Jabtonowski..., s. 76. 
dla których podjął taką, a nie inną decyzję, a także prezentował możliwe propozycje działań w kolejnych kampaniach ${ }^{46}$. Ton listów bardzo wyraźnie ukazuje, że kasztelan krakowski liczył się ze zdaniem Jana III i zależało mu, aby władca nie obarczył go odpowiedzialnością za zmianę ustalonego wcześniej planu działań.

Król mógł mediować także w sporach pomiędzy oficerami, aczkolwiek zarówno ze względu na bardzo mocną pozycję Stanisława Jabłonowskiego w armii koronnej i Kazimierza Jana Sapiehy w armii litewskiej, jak i na poprawne stosunki pomiędzy tymi dwoma hetmanami takie sytuacje zdarzały się w latach 90 . bardzo rzadko. W zasadzie jedynymi oficerami, którzy mogli sobie pozwolić na odwołanie się do Sobieskiego ze skargą na poczynania hetmana wielkiego koronnego, byli Marcin Kątski ${ }^{47}$ oraz kasztelan sandomierski i strażnik koronny Stefan Bidziński (choć ten po $1684 \mathrm{r}$. usunął się z aktywnej działalności wojskowej i poczynania Jabłonowskiego komentował raczej z pozycji postronnego obserwatora) ${ }^{48}$. Pod sam koniec panowania Jana III doszło do poważniejszego sporu pomiędzy hetmanem wielkim koronnym a rodziną Potockich, ze Szczęsnym, hetmanem polnym koronnym i wojewodą krakowskim, na czele ${ }^{49}$. Potoccy próbowali nawet za pośrednictwem świeżo spowinowaconego z nimi Szczuki doprowadzić do wyodrębnienia osobnej dywizji wojska koronnego pod dowództwem pułkownika Stefana Potockiego, łowczego koronnego ${ }^{50}$. Ich starania nie zakończyły się powodzeniem, ale niesnaski pomiędzy obydwoma hetmanami koronnymi przeciągnęły się aż do okresu bezkrólewia.

W przypadku części jednostek zakres kontroli królewskiej nad poczynaniami hetmańskimi był dużo szerszy - chodzi o jednostki gwardyjskie, czyli oddziały komputowe noszące imię króla i członków jego rodziny ${ }^{51}$. Hetman Jabłonowski przed rozłożeniem tych jednostek na leża zimowe, a także przed zmianą miejsca ich kwaterowania zazwyczaj pytał monarchę, gdzie miały zostać skierowane ${ }^{52}$. Czasami Jan III

46 S. Jabłonowski do Jana III, obóz pod Laszkowcami, 26 IX 1692, B. Czart., rkps 2699, k. 73v-75; S. Jabłonowski do Jana III, obóz pod Żwańcem, 9 X 1692 [w:] Starożytności historyczne polskie..., s. 506-509. Stanisław Jabłonowski do Jana III, obóz pod Uhrynowcami, 13 X 1692, НГАБ, f. 695, vop. 1 , rkps 99, k. 27 v.

47 M. Kątski do S.A. Szczuki, obóz pod Kułakowcami, 21 IX 1692, AGAD, APP, rkps 47, t. 2, s. 357-358, 363-366; M. Kątski do S.A. Szczuki, Lwów, 30 X 1692, AGAD, APP, rkps 47, t. 2, s. 349 351.

48 M. Wagner, Stanisław Jabłonowski..., s. 169; idem, Kampania żwaniecka..., s. 64.

49 O. T. Perkowicz SJ do A. z Gnińskich Zamoyskiej, Podkamień, 12 X 1695, AGAD, AZ, rkps 1380, s. 160-163; o. T. Perkowicz SJ do A. z Gnińskich Zamoyskiej, Lwów, 29 XII 1695, AGAD, AZ, rkps 1380, s. 172-175. Na ten temat zob. także A. Skrzypietz, Potoccy wobec stronnictwa francuskiego u schytku panowania Jana III Sobieskiego i po jego śmierci [w:] Ród Potockich w odmęcie historii (XVII-XX w.), red. Z. Janeczek, Katowice 2010, s. 39-43.

50 O. T. Perkowicz SJ do A. z Gnińskich Zamoyskiej, Lwów, 11 I 1696, AGAD, AZ, rkps 1380, s. 179.

${ }^{51}$ Na temat podległości jednostek gwardyjskich w tym okresie zob. Z. Hundert, Komputowe oddziaty rodziny królewskiej w kampanii mołdawskiej 1686 roku w świetle rozkazów i sprawozdania sejmowego hetmana wielkiego koronnego Stanistawa Jabłonowskiego [w:] Jarzmo Ligi Świętej..., s. $161-186$.

52 S. Jabłonowski do Jana III, obóz pod Mielnicą, 23 IX 1692, Starożytności historyczne polskie..., t. 2, s. 506; S. Jabłonowski do Jana III, obóz pod Rypińcami, 18 X 1695, AGAD, APP, rkps 47, t. 2, s. 597. 
sam prosił hetmana, aby wydał konkretne rozkazy oddziałom gwardii. Wiązało się to między innymi z tym, że jednostki te były potrzebne do asystowania przy uroczystościach dworskich tudzież na sejmach czy trybunałach ${ }^{53}$.

Kwestią wymagającą opracowania jest mobilizowanie przez króla szlachty do ofiarniejszego popierania wysiłku wojennego. Jeśli chodzi o pisma polemiczne i dzieła sztuki, propaganda Jana III w tym okresie doczekała się już swojej monografii ${ }^{54}$, tu pragnąłbym tylko zasygnalizować najważniejsze elementy przekazu, który Sobieski kierował do szlachty przez uniwersały i legacje sejmikowe.

Król starał się bardzo mocno podkreślać swoje ciągłe zaangażowanie w sprawy wojskowe. Swe długie pobyty w Żółkwi tłumaczył właśnie chęcią znalezienia się jak najbliżej pogranicza, aby regularnie czuwać nad pomyślnym przebiegiem działań wojennych. Dlatego też w lutym 1692 roku pisał: ,pod ustawicznym i codziennym koło szczęśliwości państw od Pana Boga nam powierzonych staraniem nie tylko same dni vigillans zabiera sollicitudo, ale częstokroć nocnych na spoczynek pozwolonych bezsenne oczy i otwarte powieki nie pozwalają momentów"55. Dzięki takiemu postawieniu sprawy Sobieski mógł sobie przypisywać nie tylko sukcesy w bitwach, w których sam brał udział (np. bitwa pod Pererytą i zdobycie Niemca w 1691 r., o których wspominano w uniwersałach w 1692 r.), ale także wszystkie zwycięstwa wojska koronnego i litewskiego nad Tatarami i Turkami (np. zwycięstwo pod Uścieszkiem w 1694 r., którym król chwalił się w uniwersałach zwołujących sejm 1695 r. $^{56}$ ). Do szczególnych rozmiarów w propagandzie monarszej urosło starcie pod Hodowem dwór niemal od razu po bitwie zaczął przyrównywać je do bitwy pod Termopilami (tyle że z pomyślnym wynikiem) ${ }^{57}$, choć sama potyczka nawet w kontekście odpierania letniego najazdu ordy budziackiej w 1694 roku nie miała dużego znaczenia. Logika wewnętrznej walki politycznej dyktowała jednak, aby w przypadku braku rzeczywistych spektakularnych sukcesów (bitwę pod Uścieszkiem stoczono dopiero w październiku) takowe wykreować.

Taki przekaz propagandowy króla był, przynajmniej oficjalnie, akceptowany przez elity wojskowe, na przykład hetman Sapieha latem 1693 roku przypisywał monarsze sukces odniesiony przez wojsko litewskie w starciu z Tatarami w okolicach Markopola i Załoziec: „tylko victrici dexterae WKM, PmM, Dobrodzieja pandere przez krew naszą wszelkie szczęśliwe successus wojska Wielkiego Księstwa

53 Zob. np. Ordynans Jm Panu Komendantowi regimentu gwardyjej Najjaśniejszego Króla Jmci, aby na usługę JKM poszedł na sejm do Grodna, obóz pod Wierzbowem, 20 X 1692, B. Czart., rkps 2699, k. $88 \mathrm{v}$.

54 A. Czarniecka, ,Nikt nie stucha mnie za życia...”. Jan III Sobieski w walce z opozycyjna propaganda (1684-1696), Warszawa 2009.

55 Uniwersał króla Jana III z 10 II 1692 r. zwołujący sejmik województwa podolskiego [w:] Akta sejmiku podolskiego in hostico 1672-1698, wyd. J. Stolicki, Kraków 2002, s. 157.

56 Uniwersał króla Jana III z 27 X 1694 r. zwołujący sejmik województwa podolskiego [w:] Akta sejmiku podolskiego..., s. 187.

57 Relacyja inkursyi tatarskiej in anno 1694 mensis junij pod Złoczów i Pomorzany, B. Czart., TN, 184, s. 241-246 (niepełne wydanie: Utamek diariusza pisanego w obozie królewskim na Podolu roku 1694, „Athenaeum. Pismo poświęcone historii, literaturze, sztukom, krytyce, itd.” (Wilno) 1848, R. V, oddz. II, s. 35-41). 
Litewskiego" 58 . Uznanie dla wizerunku Sobieskiego - zwycięskiego wodza wyrażało się także w formułach, jakimi część oficerów kończyła swoje listy do monarchy: „waleczną natenczas całuję rękę" "59 albo „niezwyciężoną całując rękę"

Jan III miał jednak świadomość, że rezultaty działań wojennych mogą być niezadowalające dla szlachty. Taki stan rzeczy tłumaczył między innymi tym, że wojska cesarskie zamiast walczyć z Osmanami na Węgrzech, są zaangażowane na zachodnioeuropejskim teatrze działań wojennych przeciw Ludwikowi XIV. Generalnie jednak Sobieski pod koniec swojego panowania próbował przekonać sejmiki, że sytuacja wojenna Rzeczypospolitej jest umiarkowanie pozytywna. W legacji na sejmiki pod koniec 1694 roku pisał zatem:

stan Rzeczypospolitej naszej jest w wojnie strasznej wprawdzie, ale nie tak ciężkiej z osobliwej nad ojczyzną naszą łaski i opatrzności Boskiej, jako za przodków naszych, sądnym dniem onę nazywaną, częścią za usilnym staraniem J.K. Mości, Pana naszego Miłościwego, divisione in socios, częścią za stąpieniem jego własnym, czego publicus albo przejrzy, albo przytrzyma neglectus ${ }^{61}$.

Innym sposobem tłumaczenia niepowodzeń (np. corocznych niszczycielskich najazdów tatarskich) było wskazywanie na niewywiązywanie się przez sejmiki ze swoich zobowiązań finansowych wobec armii i faktyczne sabotowanie decyzji sejmów. Bardzo mocno podkreślano konieczność regularnej wypłaty żołdu dla utrzymania wysokiej liczebności wojska, jak również zapowiadano zajęcie się kwestią zapewnienia stałych środków na utrzymanie fortec mołdawskich i pogranicznych ${ }^{62}$. Rozejście się trzech ostatnich sejmów za panowania Jana III bez uchwalenia konstytucji uniemożliwiło przyjęcie stosownych postanowień.

Podobnie jak w latach poprzednich Sobieski wykładał swoje prywatne pieniądze na potrzeby wojska. Co prawda Jan III po 1690 roku nie pożyczył pieniędzy na opłacenie całej ćwierci żołdu dla armii koronnej, jak zrobił to w roku $1689^{63}$, ale tylko w drugiej połowie 1692 roku prywatny skarb króla miał łożyć między innymi na zakup prochów i wołów dla artylerii koronnej, prowiantu i barwy dla Kozaków zaciąganych przez Marcina Bogusza, a także na wypłatę zaliczek dla żołnierzy służących w Soroce i Niemcu ${ }^{64}$.

58 K. J. Sapieha do Jana III, Hrubieszów, 7 VIII 1693, AGAD, ZDPap., rkps 2596, [brak paginacji].

59 K. J. Sapieha do Jana III, Wysokie Litewskie, 10 VII 1693, AGAD, ZDPap., rkps 2595, [brak paginacji].

60 S. Potocki do Jana III, Sokal, 13 VII 1693, AGAD, ZDPap., rkps 2597, [brak paginacji].

${ }_{61}$ Инструкція короля Яна III дворянству Брестскаго воеводства на сеймикъ предсеймовый, 26 X 1694 [w:] Акты издаваемые Виленскою Археографическою Коммиссиею, т. 4, Акть Брестскаго гродскаго суда, Вильна 1870, s. 217.

${ }^{62}$ Zob. np. uniwersał króla Jana III z 26 II 1693 r. zwołujący sejmik relacyjny województwa podolskiego [w:] Akta sejmiku podolskiego..., s. 168.

63 Na początku 1692 r. król domagał się szybszego spłacenia swoich wierzytelności z tego tytułu, zob. Jan III do J. Wojakowskiego, Lwów, 23 III 1692, РГАДА, f. 12, op. 1, ks. 22, k. 15v-16.

${ }_{64}$ M. Kątski do S.A. Szczuki, Lwów, 6 VIII 1692, AGAD, APP, rkps 163a, t. 20, s. 359; M. Bogusz do S.A. Szczuki, Janów k. Trembowli, 3 IX 1692, AGAD, APP, rkps 163a, t. 20, s. 306-309; S. Jabłonowski do Jana III, Lwów, 10 XI 1692 [w:] Starożytności historyczne polskie..., s. 509-510. Do grudnia 1695 r. przynajmniej część długów artylerii koronnej wobec prywatnego skarbu Jana III została spłacona 
Koniec panowania Jana III nie obfitował w spektakularne sukcesy w wojnie z Wysoką Portą. Kryzys państwa i zły stan wojsk Rzeczypospolitej uniemożliwiały odniesienie takich zwycięstw. Niemniej jednak udało się utrzymać do końca wojny zdobycze z lat poprzednich. Miało to później duże znaczenie podczas rokowań karłowickich. Zachowanie fortec mołdawskich wymagało bardzo dużego wysiłku finansowego i organizacyjnego. Wysiłek ten jest tym bardziej godny podkreślenia, że $\mathrm{w}$ omawianym okresie nie funkcjonował w zasadzie centralny organ państwa - sejm. Bardzo dobrze sytuację tę opisuje uwaga rady senatu z wiosny 1695 roku na temat potrzebnych wydatków:

przeciwko punktom rady teraźniejszej nie masz nic, co by się mogło ekscypować, bo jedne są bardzo potrzebne, a drugie bardzo słuszne i tym większej co raz potrzebuje uwagi, że do nich i na samych sejmach Rzeczpospolita żadnego nie przykłada starania, bo uchwaliwszy podatek reliquae minime curat, a przecie żadną miarą stan Rzeczypospolitej bez tego obejść nie może się, co przenosi ekspensę oprócz podatkowej płacy na żołnierza. Dlatego należeć będzie causam hanc publicarum necessitatum jak najgruntowniej poprzeć na sejmowych, da Bóg, radach. Teraz zaś, ile egestas obarczonego Skarbu pozwala tak providetur wyrażonym potrzebom ${ }^{65}$.

To samo można odnieść do nie zawsze zauważanych przez współczesnych, a także niektórych historyków wysiłków organizacyjnych podejmowanych przez króla i hetmana. Bez tych działań, bez częstej wymiany korespondencji pomiędzy wojskowymi a monarchą, wreszcie bez aktywności króla i hetmanów na forum senatu utrzymanie Soroki, Niemca, Suczawy i innych twierdz byłoby niemożliwe. Choć więc bilans ostatnich lat życia Sobieskiego nie może być określony jako pozytywny (także w wyniku błędnych decyzji politycznych samego króla), to w zakresie działalności stricte wojskowej wydaje się, że Jan III w latach 1690-1696 nie mógł dokonać więcej i wyczerpywał w zasadzie wszystkie możliwości wspierania polsko-litewskiego wysiłku wojennego.

\section{BIBLIOGRAFIA}

\section{Źródła rękopiśmienne}

Archiwum Główne Akt Dawnych w Warszawie,

Archiwum Publiczne Potockich, rkps 47, t. 2, 48, 163-163a.

Archiwum Skarbu Koronnego, dz. II, rkps 73-74.

Archiwum Zamoyskich, rkps 1380.

Zbiór dokumentów papierowych, rkps 2595-2598, 2600.

Biblioteka XX. Czartoryskich w Krakowie, rkps 426, 2563, 2699.

Teka Naruszewicza, rkps 184.

z dochodów z nowej kwarty, M. Kątski do Jana III, Lwów, 16 XI 1695, AGAD, ZDPap., rkps 2598, [brak paginacji].

${ }_{65}$ Punkta do rady na dzień 16 miesiąca kwietnia naznaczonej z Kancelaryi Koronnej od JKrMci, Warszawa, 16 IV 1695, Biblioteka Uniwersytecka w Warszawie, rkps 357, s. 39. 
Biblioteka Uniwersytecka w Warszawie, rkps 357.

Нацыянальны гістарычны архіў Беларусі, Мінск, f. 695, vop. 1, rkps 48, 55, 60, 99-100, 142.

Российский государственный архив древних актов, Москва, f. 12, op. 1, ks. 22.

\section{Źródła drukowane}

Akta sejmiku podolskiego in hostico 1672-1698, wyd. J. Stolicki, Kraków 2002.

Nagielski M., Listy z teatru działań przeciwko Turcji i Tatarom do Jana III Sobieskiego w zbiorach Archiwum Historycznego Białorusi w Mińsku [w:] Państwo, demokracja, chtopi. Studia z historii społeczno-politycznej Polski (XVII-XX w.). Tom studiów dedykowany profesorowi Romualdowi Wacławowi Turkowskiemu z okazji 65-lecia urodzin i 40-lecia pracy dydaktyczno-naukowej, red. S.J. Pastuszka, J. Sztejnbis-Zdyb, Warszawa 2016, s. 507-521.

Sarnecki K., Pamiętniki z czasów Jana Sobieskiego. Diariusz i relacje z lat 1691-1696, oprac. J. Woliński, Wrocław 1958.

Starożytności historyczne polskie, wyd. A. Grabowski, t. 2, Kraków 1840.

Ułamek diariusza pisanego w obozie królewskim na Podolu roku 1694, „Athenaeum. Pismo poświęcone historii, literaturze, sztukom, krytyce, itd.” (Wilno) 1848, R. V, oddz. II, s. $35-44$.

Volumina legum, t. V, wyd. J. Ohryzko, Petersburg 1860.

Акты издаваемые Виленскою Археографическою Коммиссиею, т. 4, Акты Брестскаго гродскаго суда, Вильна 1870.

\section{Opracowania}

Czarniecka A., ,Nikt nie stucha mnie za życia...”. Jan III Sobieski w walce z opozycyjna propaganda (1684-1696), Warszawa 2009.

Czarniecka A., Ojczyzna czy Liga Święta? Koalicja antyturecka w propagandzie za czasów Jana III Sobieskiego (1684-1696) [w:] Jarzmo Ligi Świętej? Jan III Sobieski i Rzeczpospolita w latach 1684-1696, red. D. Milew ski, Warszawa 2017, s. 81-108.

Hundert Z., Komputowe oddziały rodziny królewskiej w kampanii mołdawskiej 1686 roku $w$ świetle rozkazów i sprawozdania sejmowego hetmana wielkiego koronnego Stanisława Jabłonowskiego [w:] Jarzmo Ligi Świętej? Jan III Sobieski i Rzeczpospolita w latach 1684-1696, red. D. Milewski, Warszawa 2017, s. 161-186.

Kołodziej R., Funkcjonowanie systemu podatkowego Rzeczypospolitej i jego wpływ na wojnę z Turcja w czasach Jana III Sobieskiego [w:] Pecunia nervus belli. Z dziejów dyplomacji i stosunków międzynarodowych w XV-XVII wieku, red. M. Markiewicz, R. Skowron, F. Wolański, Prace Naukowe Uniwersytetu Śląskiego w Katowicach, nr 3448, Katowice 2016, s. 239-252.

Krupa J., Rady senatu za Jana III Sobieskiego, „Studia Historyczne” 1992, R. XXXV/3, s. $307-329$. 
Skrzypietz A., Potoccy wobec stronnictwa francuskiego u schytku panowania Jana III Sobieskiego i po jego śmierci [w:] Ród Potockich w odmęcie historii (XVII-XX w.), red. Z. Janeczek, Katowice 2010, s. 37-53.

Smolarek P., Kampania moldawska Jana III roku 1691, do druku przygotowali Z. Hundert, M. Wagner, Oświęcim 2015.

Urzędnicy centralni i nadworni Polski XIV-XVIII wieku. Spisy, red. A. Gąsiorowski, Kórnik 1992.

Wagner M., Baltazar Wilga Godzimirski - ostatni komisarz kozacki Rzeczypospolitej (1692 1699), ,Zeszyty Naukowe Uniwersytetu Jagiellońskiego. Prace Historyczne” 2016, nr 2 (143): Ukraina, Ruś w epoce nowożytnej. Instytucje i elity, red. J. Stolicki, W. Michałowski, s. 327-334.

Wagner M., Kampania żwaniecka 1684 roku, Warszawa 2013.

Wagner M., Stanisław Jabłonowski (1634-1702). Polityk i dowódca, t. II, Siedlce 1997.

Wójcik Z., Jan Sobieski 1629-1696, wyd. 2, Warszawa 1994.

Чухліб Т., Документи про фінансування козацьких полків Ватиканом та Польщею y 80-90-х роках XVII cm., „Український археографічний збірник” (Nowy Jork) 2002, Вип. 10, s. 340-356. 